Article

\title{
Synthesis, Structure and Photoluminescence Properties of 2D Organic-Inorganic Hybrid Perovskites
}

\author{
Yahui Liu ${ }^{1}$, Fang $\mathrm{Li}^{1}{ }^{1}{ }^{*}$, Fuqiang Yao ${ }^{1}$, Zhicong He ${ }^{1}$, Shuai Liu ${ }^{1}$, Litu $\mathrm{Xu}^{1}$, Xiaobo Han ${ }^{1}$ and \\ Kai Wang ${ }^{2}$ \\ 1 School of Mechanical and Electrical Engineering, Hubei Key Laboratory of Optical Information and Pattern \\ Recognition, School of Optical Information and Energy Engineering, Wuhan Institute of Technology, \\ Wuhan 430073, China; 13212799763@163.com (Y.L.); yfq15872268171@163.com (F.Y.); \\ hzc_900503987@163.com (Z.H.); 15342251052@163.com (S.L.); 15871430579@163.com (L.X.); \\ hanxiaobo@wit.edu.cn (X.H.) \\ 2 School of Physics, Huazhong University of Science \& Technology, Wuhan 430073, China; \\ kale_wong@mail.hust.edu.cn \\ * Correspondence: lifang@wit.edu.cn
}

Received: 9 November 2019; Accepted: 27 November 2019; Published: 29 November 2019

check for updates

\begin{abstract}
Two-dimensional (2D) layered hybrid organic-inorganic perovskites have potential applications in solar cells, electroluminescent devices and radiation detection because of their unique optoelectronic properties. In this paper, four 2D layered hybrid organic-inorganic halide perovskites of $\left(\mathrm{C}_{6} \mathrm{H}_{5} \mathrm{CH}_{2} \mathrm{NH}_{3}\right)_{2} \mathrm{PbCl}_{4},\left(\mathrm{C}_{6} \mathrm{H}_{5} \mathrm{CH}_{2} \mathrm{NH}_{3}\right)_{2} \mathrm{PbBr}_{4},\left(\mathrm{C}_{6} \mathrm{H}_{5} \mathrm{CH}_{2} \mathrm{NH}_{3}\right)_{2} \mathrm{PbI}_{4}$ and $\left(\mathrm{C}_{4} \mathrm{H}_{9} \mathrm{NH}_{3}\right)_{2} \mathrm{PbBr}_{4}$ were synthesized by solvent evaporation. Their crystal structure and surface morphology were studied. The effects of different halogens and organic amines on perovskites' absorption spectra were investigated, and the photoluminescence (PL) properties were studied by femtosecond ultrafast spectroscopy. The experimental results show that the four perovskites are well crystallized and oriented. With the increase of halogen atom number $(\mathrm{Cl}, \mathrm{Br}, \mathrm{I})$ in turn, the UV-Vis absorption spectra peaks of perovskites redshift due to the increasing of the layer spacing, but organic amines have little effect on the spectra of perovskites. The PL intensity increases with increasing laser power, but the lifetime decreases with increasing laser power, which is mainly due to the non-geminate recombination. This research is of great significance for realizing the spectral regulation of organic-inorganic hybrid perovskites and promoting their application in nano-photonics and optoelectronic devices.
\end{abstract}

Keywords: two-dimensional (2D) layered hybrid organic-inorganic perovskites; UV-Vis absorption spectrum; photoluminescence lifetime

\section{Introduction}

Two-dimensional layered organic-inorganic hybrid perovskites have received wide attention recently as the most competitive candidate in the photovoltaic field [1-3]. The general chemical formula of the perovskite is $\mathrm{ABX}_{3}$, in which $\mathrm{A}$-sites are the organic ammonium cations, $\mathrm{B}$-sites are the metal cations, and $\mathrm{X}$-sites are the halide anions. The $\mathrm{B}$-site cations and $\mathrm{X}$-sites anions form $\left[\mathrm{BX}_{6}\right]$ octahedrons by ionic interaction, which corner-share to constitute three-dimensional frameworks. The A-site cations are located in the framework cavity [4-6]. In contrast to the conventional 3D hybrid halide perovskites, the 2D layered $\mathrm{A}_{2} \mathrm{BX}_{4}$ crystal consists of the inorganic layers of $\left[\mathrm{BX}_{6}\right]^{2-}$ octahedra sandwiched between inter digitating bilayers of intercalated organic ammonium cations. Generally, the A cation does not directly play a major role in determining the band structure, but its size is important. A larger or smaller A cation can cause the whole lattice to expand or contract, and subsequently change the band 
structure [7]. The inorganic component offers the opportunities for high carrier mobility and a wide range of bandgap [8,9]. The organic component provides the possibility of structural diversity, highly efficient luminescence and plastic mechanical properties [10]. Importantly, these 2D layered perovskite crystals have a direct bandgap [11] with a high density of state (DOS) contributed by Pb orbitals, and thus exhibit strong light-matter interaction. In this regard, the ultrathin 2D layered perovskite crystals have shown rich optical properties, such as luminescent deep blue emission [12], exciton effect and high absorption [13]. In addition, compared with traditional polycrystalline perovskite film, 2D single-crystal perovskite promises dramatically reduced defects and notably enhanced carrier diffusion length [14]. Consequently, the improved optical and electrical properties guarantee the potential of such a new family of solution-processed semiconductors in nanoscale optoelectronic devices. An organic layer with a large energy band gap is equivalent to a potential barrier. The organic layer and inorganic layer are arranged alternately to form a multi-quantum well structure. The excitons in the inorganic layer display special optical properties, such as nonlinear absorption [15] and excitonic emission [16]. The strong exciton peaks in the optical spectra are attributed to the large exciton binding energy at room temperature [17]. Organic-inorganic hybrid perovskites have great potential applications in solar cells [18-20], electroluminescent devices [21,22], nanolasers [23-25], and photodetections [26,27].

In 2009, Miyasaka et al. initially studied solar cells with the perovskite $\mathrm{CH}_{3} \mathrm{NH}_{3} \mathrm{PbI}_{3}$, yielding a power conversion efficiency (PCE) of only 3.81\% [28]. In 2012, Kawano et al. studied the optical properties of the perovskite $\left(\mathrm{C}_{10} \mathrm{H}_{7} \mathrm{CH}_{2} \mathrm{NH}_{3}\right)_{2} \mathrm{PbBr}_{x} \mathrm{I}_{4-x}$ [29], and found that the near-resonant transition energies between Wannier and Frenkel excitons increases with an enhancement of iodine. In 2015, Slavney et al. synthesized double perovskite structure compound $\mathrm{Cs}_{2} \mathrm{AgBiBr}_{6}$ [30]. It was significantly more heat- and moisture-stable compared to the perovskite $\mathrm{CH}_{3} \mathrm{NH}_{3} \mathrm{PbI}_{3}$ and displayed a long carrier recombination lifetime. In 2017, Hu et al. studied the perovskite $\mathrm{CsPbBr}_{3}$ nanoplate electroluminescence devices, which displayed a narrow PL peak centered at $530 \mathrm{~nm}$ with a narrow full width at half-maximum of $22 \mathrm{~nm}$ [31]. In 2017, Chen et al. prepared the perovskite $\left(\mathrm{C}_{4} \mathrm{H}_{9} \mathrm{NH}_{3}\right)_{2} \mathrm{PbBr}_{4}$ by ternary solvent method and studied the effect of the crystallization temperature and solvent volume ratio on its morphology [32]. In 2018, Luo et al. studied the solar cells with the inverted planar Hetero junction perovskites, yielding a PCE of $21 \%$ due to the elimination of nonradiative charge-carrier recombination [33].

The different properties of organic and inorganic components are united in an independent composite. The inorganic component provides the opportunities for high carrier mobility and a wide range of bandgap. The organic component offers the possibility of structural diversity and high PL quantum yield. Moreover, these properties can be easily modified by changing the organic ammonium, metal or halide [34]. Currently, perovskites have been widely studied in the field of solar cells and light-emitting diodes. However, it is rare to study the PL properties of perovskites using two-photon excitation, especially to regulate its spectral properties by changing halogens in organic-inorganic hybrid perovskites. In this paper, four kinds of perovskites- $\left(\mathrm{C}_{6} \mathrm{H}_{5} \mathrm{CH}_{2} \mathrm{NH}_{3}\right)_{2} \mathrm{PbCl}_{4}$, $\left(\mathrm{C}_{6} \mathrm{H}_{5} \mathrm{CH}_{2} \mathrm{NH}_{3}\right)_{2} \mathrm{PbBr}_{4},\left(\mathrm{C}_{6} \mathrm{H}_{5} \mathrm{CH}_{2} \mathrm{NH}_{3}\right)_{2} \mathrm{PbI}_{4}$ and $\left(\mathrm{C}_{4} \mathrm{H}_{9} \mathrm{NH}_{3}\right)_{2} \mathrm{PbBr}_{4}$-were synthesized by solvent evaporation. The laser power effect on the PL intensity and lifetime was investigated with femtosecond laser via two-photon excitation. The results show that the PL properties of perovskite can be regulated in a certain range. Using this technology to change the luminescence peak can promote the application of nano-photonics and optoelectronic devices, and promote the development of near-infrared band nano-lasers, which can be better used in optical fiber communication.

\section{Experiment}

\subsection{Synthesis of Organic Ammonium Salts}

Firstly, a certain volume of the organic amine, benzylamine $(0.84 \mathrm{~mL}, 10 \mathrm{mmol})$ or n-butylamine $(1.11 \mathrm{~mL}, 10 \mathrm{mmol})$, was added into anhydrous ethanol $(10 \mathrm{~mL})$ in a $50 \mathrm{~mL}$ breaker at room temperature. Secondly, the haloid acid, hydrochloric acid $(1.14 \mathrm{~mL}, 10 \mathrm{mmol}, 38 \mathrm{wt} \%)$, hydrobromide acid $(1.36 \mathrm{~mL}$, $10 \mathrm{mmol}, 40 \mathrm{wt} \%)$ or hydroiodic acid $(1.62 \mathrm{~mL}, 10 \mathrm{mmol}, 45 \mathrm{wt} \%)$ was dropwise added into the breaker. 
Then, the mixtures were heated to $50{ }^{\circ} \mathrm{C}$ and stirred for half an hour by heating magnetic stirrer and then cooled at room temperature after the mixtures had been fully reacted. Subsequently, a crude oil-like product was obtained by evaporating the solvent in a rotatory evaporator at $60{ }^{\circ} \mathrm{C}$. The crude product (the halide amine salt) was washed by stirring for $30 \mathrm{~min}$ with a certain volume of anhydrous ethanol, which was repeated three times, and then finally dried at $60^{\circ} \mathrm{C}$ in a vacuum oven for $24 \mathrm{~h}$. The obtained organic ammonium salt was stored in an airtight container for later use.

\subsection{Synthesis of Perovskite Crystals}

The organic ammonium salts and $\mathrm{PbX}_{2}$ were dissolved in $N, N$-dimethylformamide (DMF) in a molar ratio of 2:1, respectively. The mixtures were heated at $50{ }^{\circ} \mathrm{C}$ and stirred for $1 \mathrm{~h}$, then the perovskites were prepared by solvent evaporation. The products were evaporated after washing with ethanol. Figure 1 shows the flow chart of synthesis of organic-inorganic hybrid perovskite crystals.

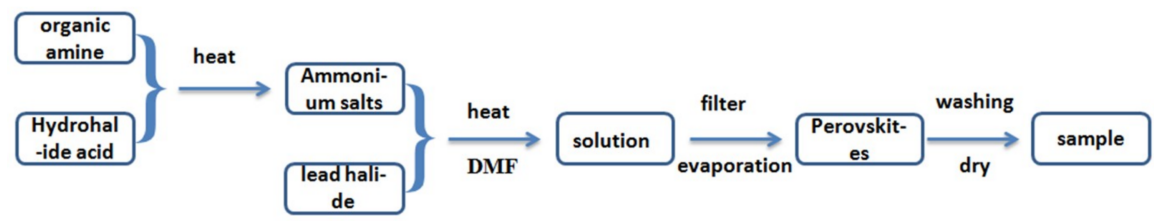

Figure 1. The flow chart of the synthesis of organic-inorganic hybrid perovskite crystals.

\subsection{Synthesis of Perouskitenanosheet}

The perovskite crystals were ground into powders in a mortar. The samples of a certain quality were put into a mortar and ground repeatedly to form powder with uniform particle size. The powder was transferred to a glass bottle and a certain volume of hydrous ethanol was added. The glass bottle was placed into an ultrasonic cleaner (the power was set at $100 \mathrm{~mW}$ and the time was set at $20 \mathrm{~min}$ ). After the end of ultrasonic oscillation, a certain volume of solution was sucked into another glass bottle with a rubber head dropper, and the glass bottle was placed into a low-speed centrifuge (the rotation speed was set at $5000 \mathrm{r} / \mathrm{min}$ and the time was set at $5 \mathrm{~min}$ ). After centrifugation, a certain volume of supernatant liquor was added to clean silicon slice. After drying at room temperature, perovskite nanoparticles were obtained and stored in a sealed container with constant temperature and humidity. The chemical reaction equations during the experiment are shown as follows:

$$
\begin{gathered}
\mathrm{C}_{4} \mathrm{H}_{9} \mathrm{NH}_{2}+\mathrm{HX} \Rightarrow \mathrm{C}_{4} \mathrm{H}_{9} \mathrm{NH}_{3} \mathrm{X} \\
2 \mathrm{C}_{4} \mathrm{H}_{9} \mathrm{NH}_{3} \mathrm{X}+\mathrm{PbX} 2 \Rightarrow\left(\mathrm{C}_{4} \mathrm{H}_{9} \mathrm{NH}_{3}\right)_{2} \mathrm{PbX}_{4} \\
\mathrm{C}_{6} \mathrm{H}_{5} \mathrm{CH}_{2} \mathrm{NH}_{2}+\mathrm{HX} \Rightarrow \mathrm{C}_{6} \mathrm{H}_{5} \mathrm{CH}_{2} \mathrm{NH}_{3} \mathrm{X} \\
2 \mathrm{C}_{6} \mathrm{H}_{5} \mathrm{CH}_{2} \mathrm{NH}_{3} \mathrm{X}+\mathrm{PbX} \mathrm{X}_{2} \Rightarrow\left(\mathrm{C}_{6} \mathrm{H}_{5} \mathrm{CH}_{2} \mathrm{NH}_{3}\right)_{2} \mathrm{PbX}_{4}
\end{gathered}
$$

\subsection{Characterization}

The crystal structure of the sample was analyzed by X-ray diffraction (Bruker AXS, D8 Advance, Germany). The working voltage was $40 \mathrm{kV}$, the current was $40 \mathrm{~mA}$, and the scanning speed was $0.02 \%$. The surface morphology and electron diffraction of the sample were observed by transmission electron microscope (JEOL, JEM-2000, Japan), and the working voltage was $200 \mathrm{kV}$. The absorption spectrum of the sample was measured by the UV-Visible spectrometer (PerkinElmer, Lambda 35, America), and the scanning range was $200-800 \mathrm{~nm}$. The PL spectrum of the sample was measured by F-380 fluorescence spectrometer. The radiation source was the $\mathrm{He}-\mathrm{Cd}$ laser, the excitation wavelength was $325 \mathrm{~nm}$, and the spectral measurement range was $300-800 \mathrm{~nm}$. 


\subsection{The Experimental Optical Path}

In this study, femtosecond pulsed titanium sapphire laser (Vitara) and time correlation single photon counter (TCSPC) were used to study the two-photon PL spectrum and PL lifetime of samples. The central wavelength was $800 \mathrm{~nm}$, the pulse width was $8 \mathrm{fs}$, and the repetition frequency was $80 \mathrm{MHz}$. PL spectra of samples were recorded by spectrometer and PL lifetime of samples was measured by TCSPC. Experimental tests are usually carried out in dark rooms at room temperature, which can minimize experimental errors caused by natural light. Figure 2 shows the optical path of the photoluminescence test system used in the experiment, in which A1 and A2 are half wave plates, B is the polarizer, $\mathrm{C} 1$ and $\mathrm{C} 2$ are $750 \mathrm{~nm}$ low pass filters, M1-M7 and M9-M11 are reflectors, M8 is a reflex, $\mathrm{O} 1$ and $\mathrm{O} 2$ are objectives (the numerical aperture was 0.65 ), and $\mathrm{CCD}$ is a charge couple device.

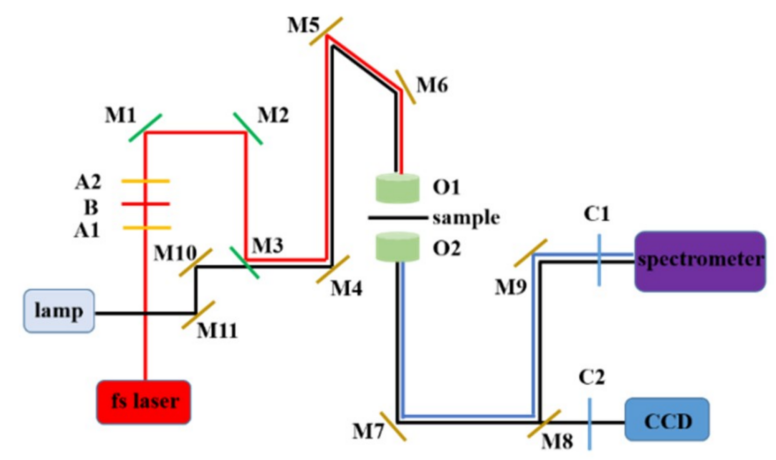

Figure 2. The experiment optical path of photoluminescence test system.

The experimental results can be fitted to a biexponential decay function:

$$
I=A_{1} \exp \left(-t / \tau_{1}\right)+A_{2} \exp \left(-t / \tau_{2}\right)
$$

where $\tau_{1}$ and $\tau_{2}$ are the radiative and nonradiative decay lifetime, respectively.

\section{Results and Discussion}

\subsection{Structure Characterization}

Figure $3 \mathrm{a}, \mathrm{c}, \mathrm{e}, \mathrm{g}$ shows crystal structures of $\left(\mathrm{C}_{6} \mathrm{H}_{5} \mathrm{CH}_{2} \mathrm{NH}_{3}\right)_{2} \mathrm{PbCl}_{4},\left(\mathrm{C}_{6} \mathrm{H}_{5} \mathrm{CH}_{2} \mathrm{NH}_{3}\right)_{2} \mathrm{PbBr}_{4}$, $\left(\mathrm{C}_{6} \mathrm{H}_{5} \mathrm{CH}_{2} \mathrm{NH}_{3}\right)_{2} \mathrm{PbI}_{4}$ and $\left(\mathrm{C}_{4} \mathrm{H}_{9} \mathrm{NH}_{3}\right)_{2} \mathrm{PbBr}_{4}$, respectively. It can be observed that the four perovskites exhibit two-dimensional layered structures. [PbX6] octahedrons are connected by common vertices, and organic amine cation is evenly filled on both sides of the octahedron in opposite ways. The molecular layers of $\left(\mathrm{C}_{6} \mathrm{H}_{5} \mathrm{CH}_{2} \mathrm{NH}_{3}\right)_{2} \mathrm{PbCl}_{4}$ and $\left(\mathrm{C}_{6} \mathrm{H}_{5} \mathrm{CH}_{2} \mathrm{NH}_{3}\right)_{2} \mathrm{PbBr}_{4}$ stack along the axis. The molecular layers of $\left(\mathrm{C}_{6} \mathrm{H}_{5} \mathrm{CH}_{2} \mathrm{NH}_{3}\right)_{2} \mathrm{PbI}_{4}$ stack along the $\mathrm{b}$ axis. The molecular layers of $\left(\mathrm{C}_{4} \mathrm{H}_{9} \mathrm{NH}_{3}\right)_{2} \mathrm{PbBr}_{4}$ stack along the $\mathrm{c}$ axis. The organic amine cation of $\left(\mathrm{C}_{6} \mathrm{H}_{5} \mathrm{CH}_{2} \mathrm{NH}_{3}\right)_{2} \mathrm{PbBr}_{4}$ showed disorder and occupied two equivalent positions. The organic amine cation of $\left(\mathrm{C}_{6} \mathrm{H}_{5} \mathrm{CH}_{2} \mathrm{NH}_{3}\right)_{2} \mathrm{PbCl}_{4},\left(\mathrm{C}_{6} \mathrm{H}_{5} \mathrm{CH}_{2} \mathrm{NH}_{3}\right)_{2} \mathrm{PbI}_{4}$ and $\left(\mathrm{C}_{4} \mathrm{H}_{9} \mathrm{NH}_{3}\right)_{2} \mathrm{PbBr}_{4}$ showed order and occupied an equivalent position.

Figure $3 \mathrm{~b}$, d, f, h shows the basic unit structure of $\left(\mathrm{C}_{6} \mathrm{H}_{5} \mathrm{CH}_{2} \mathrm{NH}_{3}\right)_{2} \mathrm{PbCl}_{4},\left(\mathrm{C}_{6} \mathrm{H}_{5} \mathrm{CH}_{2} \mathrm{NH}_{3}\right)_{2} \mathrm{PbBr}_{4}$, $\left(\mathrm{C}_{6} \mathrm{H}_{5} \mathrm{CH}_{2} \mathrm{NH}_{3}\right)_{2} \mathrm{PbI}_{4}$ and $\left(\mathrm{C}_{4} \mathrm{H}_{9} \mathrm{NH}_{3}\right)_{2} \mathrm{PbBr}_{4}$. The bond lengths are given in Table 1 . 

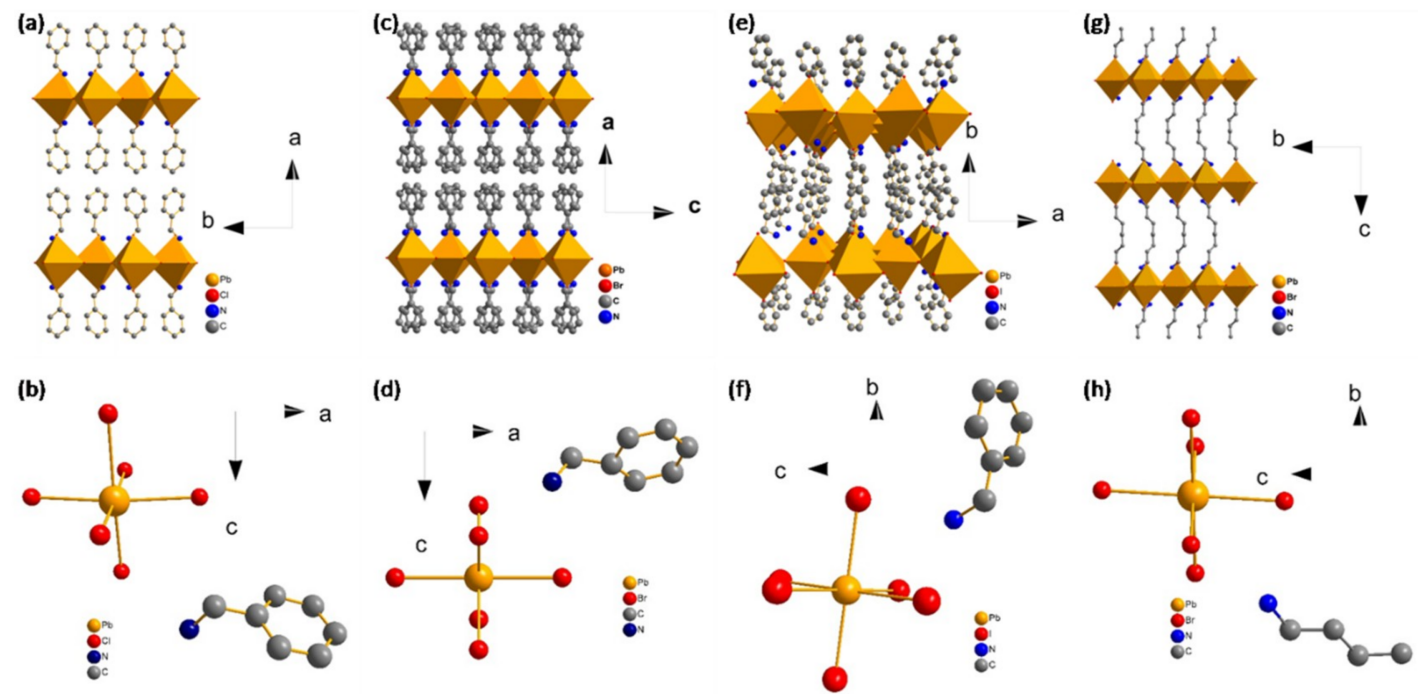

Figure 3. (a) The crystal structure diagram and (b) the basic unit structure diagram of $\left(\mathrm{C}_{6} \mathrm{H}_{5} \mathrm{CH}_{2} \mathrm{NH}_{3}\right)_{2} \mathrm{PbCl}_{4}$; (c) the crystal structure diagram and (d) the basic unit structure diagram of $\left(\mathrm{C}_{6} \mathrm{H}_{5} \mathrm{CH}_{2} \mathrm{NH}_{3}\right)_{2} \mathrm{PbBr}_{4}$; (e) the crystal structure diagram and (f) the basic unit structure diagram of $\left(\mathrm{C}_{6} \mathrm{H}_{5} \mathrm{CH}_{2} \mathrm{NH}_{3}\right)_{2} \mathrm{PbI}_{4} ;(\mathrm{g})$ the crystal structure diagram and (h) the basic unit structure diagram of $\left(\mathrm{C}_{4} \mathrm{H}_{9} \mathrm{NH}_{3}\right)_{2} \mathrm{PbBr}_{4}$. The hydrogen linked to the carbon atom is omitted.

Table 1. Length of four samples.

\begin{tabular}{|c|c|c|c|c|}
\hline & & & & Unit: nm \\
\hline & $\left(\mathrm{C}_{6} \mathrm{H}_{5} \mathrm{CH}_{2} \mathrm{NH}_{3}\right)_{2} \mathrm{PbCl}_{4}$ & $\left(\mathrm{C}_{6} \mathrm{H}_{5} \mathrm{CH}_{2} \mathrm{NH}_{3}\right)_{2} \mathrm{PbBr}_{4}$ & $\left(\mathrm{C}_{6} \mathrm{H}_{5} \mathrm{CH}_{2} \mathrm{NH}_{3}\right)_{2} \mathrm{PbI}_{4}$ & $\left(\mathrm{C}_{4} \mathrm{H}_{9} \mathrm{NH}_{3}\right)_{2} \mathrm{PbBr}_{4}$ \\
\hline $\mathrm{C} 1-\mathrm{C} 2$ & 0.1463 & 0.1494 & 0.1481 & 0.1429 \\
\hline $\mathrm{C} 2-\mathrm{C} 3$ & 0.1392 & 0.1385 & 0.1363 & 0.1482 \\
\hline $\mathrm{C} 3-\mathrm{C} 4$ & 0.135 & 0.1386 & 0.1372 & 0.1438 \\
\hline C4-C5 & 0.1369 & 0.1384 & 0.1342 & 0.1461 \\
\hline C5-C6 & 0.1322 & 0.1389 & 0.134 & - \\
\hline $\mathrm{C} 6-\mathrm{C} 7$ & 0.1412 & 0.1387 & 0.1358 & - \\
\hline $\mathrm{C} 7-\mathrm{C} 2$ & 0.1371 & 0.1387 & 0.1367 & - \\
\hline $\mathrm{C} 1-\mathrm{N}$ & 0.1521 & 0.1447 & 0.1507 & - \\
\hline $\mathrm{Pb}-\mathrm{X} 1$ & 0.2877 & 0.2998 & 0.3224 & 0.3005 \\
\hline $\mathrm{Pb}-\mathrm{X} 2$ & 0.2841 & 0.2979 & 0.3203 & 0.2938 \\
\hline $\mathrm{Pb}-\mathrm{X} 3$ & 0.2886 & 0.2982 & 0.3198 & 0.2973 \\
\hline
\end{tabular}

Figure 4a-d shows X-ray powder diffraction patterns of $\left(\mathrm{C}_{6} \mathrm{H}_{5} \mathrm{CH}_{2} \mathrm{NH}_{3}\right)_{2} \mathrm{PbCl}_{4}$, $\left(\mathrm{C}_{6} \mathrm{H}_{5} \mathrm{CH}_{2} \mathrm{NH}_{3}\right)_{2} \mathrm{PbBr}_{4},\left(\mathrm{C}_{6} \mathrm{H}_{5} \mathrm{CH}_{2} \mathrm{NH}_{3}\right)_{2} \mathrm{PbI}_{4}$ and $\left(\mathrm{C}_{4} \mathrm{H}_{9} \mathrm{NH}_{3}\right)_{2} \mathrm{PbBr}_{4}$, respectively. The diffraction peaks of $\left(\mathrm{C}_{6} \mathrm{H}_{5} \mathrm{CH}_{2} \mathrm{NH}_{3}\right)_{2} \mathrm{PbCl}_{4}$ powder appear at $6.52^{\circ}, 10.52^{\circ}, 15.80^{\circ}, 21.12^{\circ}, 26.49^{\circ}, 31.92^{\circ}$ and $37.42^{\circ}$; these diffraction peaks correspond to the crystal surface of the vertical a axis in (200), (400), (600), (800), (1000), (1200) and (1400). The diffraction peaks of $\left(\mathrm{C}_{6} \mathrm{H}_{5} \mathrm{CH}_{2} \mathrm{NH}_{3}\right)_{2} \mathrm{PbBr}_{4}$ powder appear at $6.41^{\circ}$, $10.63^{\circ}, 15.96^{\circ}, 21.32^{\circ}, 26.72^{\circ}, 32.18^{\circ}$ and $37.73^{\circ}$. These diffraction peaks correspond to the crystal surface of the vertical a axis in (200), (400), (600), (800), (1000), (1200) and (1400). The diffraction peaks of $\left(\mathrm{C}_{6} \mathrm{H}_{5} \mathrm{CH}_{2} \mathrm{NH}_{3}\right)_{2} \mathrm{PbI}_{4}$ powder appear at $6.14^{\circ}, 12.29^{\circ}, 18.48^{\circ}, 24.73^{\circ}, 31.05^{\circ}$ and $37.47^{\circ}$. These diffraction peaks correspond to the crystal surface of the vertical b axis in (020), (040), (060), (080), (0100) and (0120). The diffraction peaks of $\left(\mathrm{C}_{4} \mathrm{H}_{9} \mathrm{NH}_{3}\right)_{2} \mathrm{PbBr}_{4}$ powder appear at $6.42^{\circ}, 12.85^{\circ}, 19.33^{\circ}, 25.87^{\circ}$ and $32.50^{\circ}$. These diffraction peaks correspond to the crystal surface of the vertical c axis in (002), (004), (006), (008), (0010) and (0012).

The X-ray powder diffraction results show that the four perovskites with sharp diffraction peaks have very high crystallinity. As shown in Figure $4 \mathrm{a}$, the diffraction peaks of $\left(\mathrm{C}_{6} \mathrm{H}_{5} \mathrm{CH}_{2} \mathrm{NH}_{3}\right)_{2} \mathrm{PbCl}_{4}$ 
are parallel to the bc plane ( $\mathrm{X00}, \mathrm{X}=2,4,6 \ldots .$.$) , indicating that the \left(\mathrm{C}_{6} \mathrm{H}_{5} \mathrm{CH}_{2} \mathrm{NH}_{3}\right)_{2} \mathrm{PbCl}_{4}$ has a strong preferential orientation, and the organic component and inorganic component grow and extend alternately in the bc plane to form a two-dimensional structure of the vertical a axis. As shown in Figure $4 \mathrm{~b}$, the diffraction peaks of $\left(\mathrm{C}_{6} \mathrm{H}_{5} \mathrm{CH}_{2} \mathrm{NH}_{3}\right)_{2} \mathrm{PbBr}_{4}$ are parallel to the bc plane (X00, $\mathrm{X}=2,4,6 \ldots . .$.$) , indicating that the \left(\mathrm{C}_{6} \mathrm{H}_{5} \mathrm{CH}_{2} \mathrm{NH}_{3}\right)_{2} \mathrm{PbBr}_{4}$ has a strong preferential orientation, and the organic component and inorganic component grow and extend alternately in the bc plane to form a two-dimensional structure of the vertical a axis. As shown in Figure $4 \mathrm{c}$, the diffraction peaks of $\left(\mathrm{C}_{6} \mathrm{H}_{5} \mathrm{CH}_{2} \mathrm{NH}_{3}\right)_{2} \mathrm{PbI}_{4}$ are parallel to the ac plane $(0 \mathrm{X} 0, \mathrm{X}=2,4,6 \ldots \ldots)$, indicating that the $\left(\mathrm{C}_{6} \mathrm{H}_{5} \mathrm{CH}_{2} \mathrm{NH}_{3}\right)_{2} \mathrm{PbI}_{4}$ has a strong preferential orientation, and the organic component and inorganic component grow and extend alternately in the ac plane to form a two-dimensional structure of the vertical $b$ axis. As shown in Figure $4 d$, the diffraction peaks of $\left(\mathrm{C}_{4} \mathrm{H}_{9} \mathrm{NH}_{3}\right)_{2} \mathrm{PbBr}_{4}$ are parallel to the ab plane (00X, $\mathrm{X}=2,4,6 \ldots \ldots)$, indicating that the $\left(\mathrm{C}_{4} \mathrm{H}_{9} \mathrm{NH}_{3}\right)_{2} \mathrm{PbBr}_{4}$ has a strong preferential orientation, and the organic part is parallel to the inorganic part and extends in the ab plane. The organic component and inorganic component grow and extend alternately in the ab plane to form a two-dimensional structure of the vertical $\mathrm{c}$ axis [32,35].
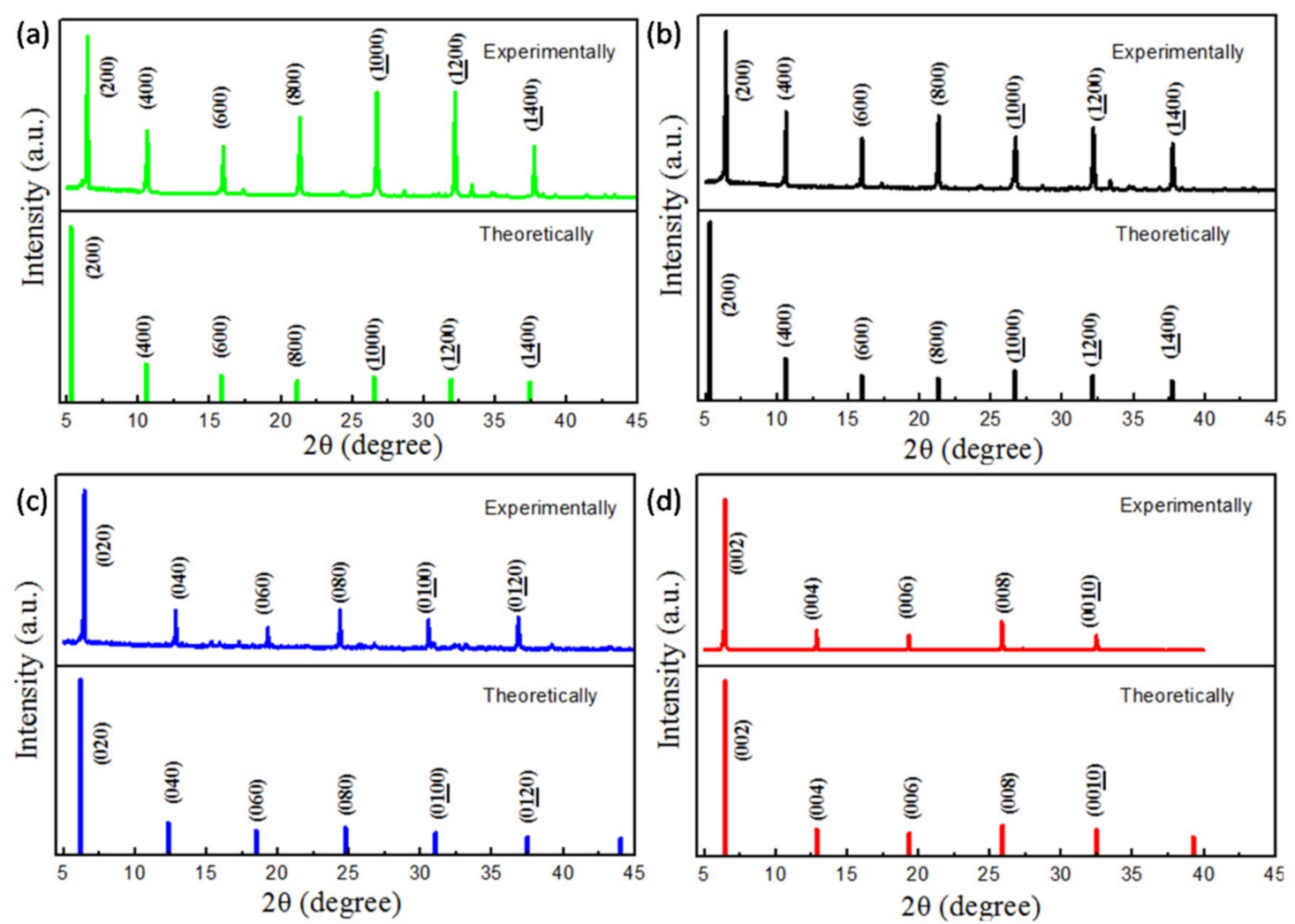

Figure 4. The $\mathrm{X}$-ray powder diffraction patterns (experimental view and theoretical view) of (a) $\left(\mathrm{C}_{6} \mathrm{H}_{5} \mathrm{CH}_{2} \mathrm{NH}_{3}\right)_{2} \mathrm{PbCl}_{4}$ (green), (b) $\left(\mathrm{C}_{6} \mathrm{H}_{5} \mathrm{CH}_{2} \mathrm{NH}_{3}\right)_{2} \mathrm{PbBr}_{4}$ (black), (c) $\left(\mathrm{C}_{6} \mathrm{H}_{5} \mathrm{CH}_{2} \mathrm{NH}_{3}\right)_{2} \mathrm{PbI}_{4}$ (blue) and (d) $\left(\mathrm{C}_{4} \mathrm{H}_{9} \mathrm{NH}_{3}\right)_{2} \mathrm{PbBr}_{4}$ (red).

The thickness of the single layer in the molecular structure of perovskite is the length of one layer $\left[\mathrm{PbX}_{6}\right]$ of octahedron plus two layers of organic amine cation. The interlayer spacing of perovskite molecules can be calculated by Bragg formula:

$$
2 d \sin \theta=k \lambda
$$


where $d$ is the interlayer spacing, $\theta$ is the diffraction degree, $\mathrm{k}$ is the diffraction class, and $\lambda$ is the wavelength of $X$-ray. The interlayer spacing of $\left(\mathrm{C}_{6} \mathrm{H}_{5} \mathrm{CH}_{2} \mathrm{NH}_{3}\right)_{2} \mathrm{PbCl}_{4},\left(\mathrm{C}_{6} \mathrm{H}_{5} \mathrm{CH}_{2} \mathrm{NH}_{3}\right)_{2} \mathrm{PbBr}_{4}$, $\left(\mathrm{C}_{6} \mathrm{H}_{5} \mathrm{CH}_{2} \mathrm{NH}_{3}\right)_{2} \mathrm{PbI}_{4}$ and $\left(\mathrm{C}_{4} \mathrm{H}_{9} \mathrm{NH}_{3}\right)_{2} \mathrm{PbBr}_{4}$ are $1.35 \mathrm{~nm}, 1.44 \mathrm{~nm}, 1.68 \mathrm{~nm}$ and $1.376 \mathrm{~nm}$, respectively.

The results show that the layer spacing of $\left(\mathrm{C}_{6} \mathrm{H}_{5} \mathrm{CH}_{2} \mathrm{NH}_{3}\right)_{2} \mathrm{PbCl}_{4},\left(\mathrm{C}_{6} \mathrm{H}_{5} \mathrm{CH}_{2} \mathrm{NH}_{3}\right)_{2} \mathrm{PbBr}_{4}$, and $\left(\mathrm{C}_{6} \mathrm{H}_{5} \mathrm{CH}_{2} \mathrm{NH}_{3}\right)_{2} \mathrm{PbI}_{4}$ increases successively. This is because the atomic radius of chlorine, bromine and iodine increases successively, and the volume of crystal cells of the three kinds of perovskite also increases correspondingly, and the organic parts and inorganic metal parts of the three kinds of perovskite molecules are the same, so their layer spacing shows a trend of increasing successively. Crystal data of the four kinds of perovskites are shown in Table 2.

Table 2. Crystal data of $\left(\mathrm{C}_{6} \mathrm{H}_{5} \mathrm{CH}_{2} \mathrm{NH}_{3}\right)_{2} \mathrm{PbCl}_{4},\left(\mathrm{C}_{6} \mathrm{H}_{5} \mathrm{CH}_{2} \mathrm{NH}_{3}\right)_{2} \mathrm{PbBr}_{4},\left(\mathrm{C}_{6} \mathrm{H}_{5} \mathrm{CH}_{2} \mathrm{NH}_{3}\right)_{2} \mathrm{PbI}_{4}$ and $\left(\mathrm{C}_{4} \mathrm{H}_{9} \mathrm{NH}_{3}\right)_{2} \mathrm{PbBr}_{4}$.

\begin{tabular}{ccccc}
\hline Formula & $\left.\mathbf{( C}_{\mathbf{7}} \mathbf{H}_{\mathbf{1 0}} \mathbf{N}\right)_{\mathbf{2}} \mathbf{P b C l}_{\mathbf{4}}$ & $\left.\mathbf{( C}_{\mathbf{7}} \mathbf{H}_{\mathbf{1 0}} \mathbf{N}\right)_{\mathbf{2}} \mathbf{P b B r}_{\mathbf{4}}$ & $\left.\mathbf{( C}_{\mathbf{7}} \mathbf{H}_{\mathbf{1 0}} \mathbf{N}\right)_{\mathbf{2}} \mathbf{P b I}_{\mathbf{4}}$ & $\mathbf{( C}_{\mathbf{4}} \mathbf{H}_{\mathbf{1 2}} \mathbf{N} \mathbf{~}_{\mathbf{2}} \mathbf{P b B r}_{\mathbf{4}}$ \\
\hline Weight & 565 & 743 & 931 & 675 \\
Temperature (K) & 293 & 293 & 293 & 323 \\
Crystal system & orthorhombic & Orthorhombic & orthorhombic & orthorhombic \\
Space group & $\mathrm{Cmc} 2_{1}$ & Cmca & Pbca & Pbca \\
a (A) & 33.619 & 33.394 & 8.689 & 8.22 \\
b (A) & 7.819 & 8.153 & 28.78 & 8.33 \\
$\mathrm{c}(\mathrm{A})$ & 7.728 & 8.131 & 9.162 & 27.62 \\
$\mathrm{~V}\left(\mathrm{~A}^{3}\right)$ & 2034 & 2214 & 2291 & 1895 \\
$\mathrm{Z}$ & 4 & 4 & 4 & 4 \\
$\rho\left(\mathrm{g} / \mathrm{cm}^{3}\right)$ & 1.846 & 2.230 & 2.699 & 2.370 \\
$\mu\left(\mathrm{mm}^{-1}\right)$ & 8.814 & 14.836 & 17.34 & 17.30 \\
\hline
\end{tabular}

\subsection{Morphology Characterization}

Figure 5 shows the bright field TEM (Transmission Electron Microscope) images, HR-TEM (High Resolution Transmission Electron Microscope) images and SAED (selected area electron diffraction) pattern of the perovskite $\left(\mathrm{C}_{6} \mathrm{H}_{5} \mathrm{CH}_{2} \mathrm{NH}_{3}\right)_{2} \mathrm{PbCl}_{4},\left(\mathrm{C}_{6} \mathrm{H}_{5} \mathrm{CH}_{2} \mathrm{NH}_{3}\right)_{2} \mathrm{PbBr}_{4},\left(\mathrm{C}_{6} \mathrm{H}_{5} \mathrm{CH}_{2} \mathrm{NH}_{3}\right)_{2} \mathrm{PbI}_{4}$ and $\left(\mathrm{C}_{4} \mathrm{H}_{9} \mathrm{NH}_{3}\right)_{2} \mathrm{PbBr}_{4}$ nanosheets. The TEM shows different shapes and different sizes of perovskite nanosheets, which correspond to different thicker perovskite nanosheets. The local size of $\left(\mathrm{C}_{6} \mathrm{H}_{5} \mathrm{CH}_{2} \mathrm{NH}_{3}\right)_{2} \mathrm{PbCl}_{4}$ is $800 \mathrm{~nm}$. The lattice spacing is $0.261 \mathrm{~nm}$ with the growth direction along [100], indicating the orthorhombic phase space group $\mathrm{Cmc}_{1}$. The local size of $\left(\mathrm{C}_{6} \mathrm{H}_{5} \mathrm{CH}_{2} \mathrm{NH}_{3}\right)_{2} \mathrm{PbBr}_{4}$ is $600 \mathrm{~nm}$. The lattice spacing is $0.294 \mathrm{~nm}$ with the growth direction along [100], indicating the orthorhombic phase space group Cmca. The local size of $\left(\mathrm{C}_{6} \mathrm{H}_{5} \mathrm{CH}_{2} \mathrm{NH}_{3}\right)_{2} \mathrm{PbI}_{4}$ is $1000 \mathrm{~nm}$. The lattice spacing is $0.357 \mathrm{~nm}$ with the growth direction along [010], indicating the orthorhombic phase space group Pbca. The local size of $\left(\mathrm{C}_{4} \mathrm{H}_{9} \mathrm{NH}_{3}\right)_{2} \mathrm{PbBr}_{4}$ is $1600 \mathrm{~nm}$. The lattice spacing is $0.263 \mathrm{~nm}$ with the growth direction along [001], indicating the orthorhombic phase space group Pbca. 


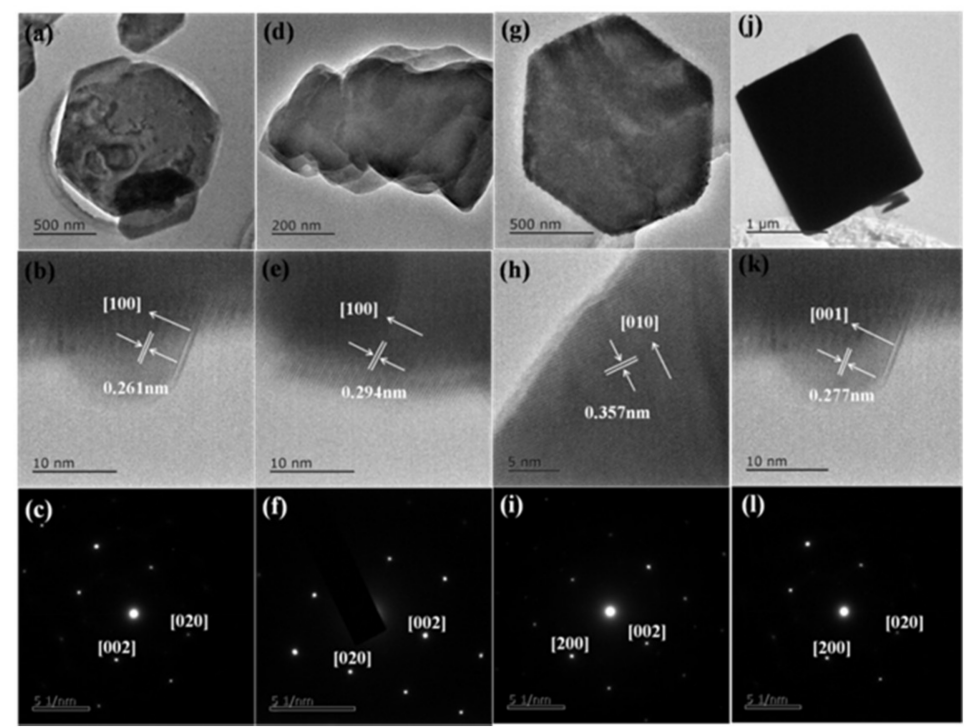

Figure 5. (a) The bright field TEM images, (b) HR-TEM images and (c) SAED pattern of the perovskite $\left(\mathrm{C}_{6} \mathrm{H}_{5} \mathrm{CH}_{2} \mathrm{NH}_{3}\right)_{2} \mathrm{PbCl}_{4}$ nanosheets; (d) the bright field TEM images, (e) HR-TEM images and (f) SAED pattern of the perovskite $\left(\mathrm{C}_{6} \mathrm{H}_{5} \mathrm{CH}_{2} \mathrm{NH}_{3}\right)_{2} \mathrm{PbB}_{4}$ nanosheets; (g) the bright field TEM images, (h) HR-TEM images and (i) SAED pattern of the perovskite $\left(\mathrm{C}_{6} \mathrm{H}_{5} \mathrm{CH}_{2} \mathrm{NH}_{3}\right)_{2} \mathrm{PbI}_{4}$ nanosheets; (j) the bright field TEM images, (k) HR-TEM images and (1) SAED pattern of the perovskite $\left(\mathrm{C}_{4} \mathrm{H}_{9} \mathrm{NH}_{3}\right)_{2} \mathrm{PbBr}_{4}$ nanosheets.

\subsection{Absorption Spectrum}

Figure 6 shows the UV-Vis absorption spectra of the perovskites $\left(\mathrm{C}_{6} \mathrm{H}_{5} \mathrm{CH}_{2} \mathrm{NH}_{3}\right)_{2} \mathrm{PbCl}_{4}$, $\left(\mathrm{C}_{6} \mathrm{H}_{5} \mathrm{CH}_{2} \mathrm{NH}_{3}\right)_{2} \mathrm{PbBr}_{4},\left(\mathrm{C}_{6} \mathrm{H}_{5} \mathrm{CH}_{2} \mathrm{NH}_{3}\right)_{2} \mathrm{PbI}_{4}$ and $\left(\mathrm{C}_{4} \mathrm{H}_{9} \mathrm{NH}_{3}\right)_{2} \mathrm{PbBr}_{4}$. The absorption peaks are located at $346 \mathrm{~nm}(3.47 \mathrm{eV}), 392 \mathrm{~nm}(3.16 \mathrm{eV}), 516 \mathrm{~nm}(2.33 \mathrm{eV})$ and $416 \mathrm{~nm}(2.96 \mathrm{eV})$, respectively. It can be seen that the absorption spectra of $\left(\mathrm{C}_{6} \mathrm{H}_{5} \mathrm{CH}_{2} \mathrm{NH}_{3}\right)_{2} \mathrm{PbCl}_{4},\left(\mathrm{C}_{6} \mathrm{H}_{5} \mathrm{CH}_{2} \mathrm{NH}_{3}\right)_{2} \mathrm{PbBr}_{4}$ and $\left(\mathrm{C}_{6} \mathrm{H}_{5} \mathrm{CH}_{2} \mathrm{NH}_{3}\right)_{2} \mathrm{PbI}_{4}$ have a redshift. When the organic part remains unchanged, the absorption peak of the inorganic part increases, with the atomic radius of chlorine, bromine and iodine increasing in turn. As the atomic radius of chlorine, bromine and iodine increases in turn, the framework of $\mathrm{PbX}_{2}$ in the inorganic layer increases in turn, and the band gap of $\mathrm{PbCl}_{2}, \mathrm{PbBr}_{2}$ and $\mathrm{PbI}_{2}$ in the inorganic part decreases in turn, resulting in the decrease of exciton binding energy in turn, so the exciton absorption peak shifts red. Therefore, the absorption spectrum of $\left(\mathrm{C}_{6} \mathrm{H}_{5} \mathrm{CH}_{2} \mathrm{NH}_{3}\right)_{2} \mathrm{PbCl}_{4},\left(\mathrm{C}_{6} \mathrm{H}_{5} \mathrm{CH}_{2} \mathrm{NH}_{3}\right)_{2} \mathrm{PbBr}_{4}$ and $\left(\mathrm{C}_{6} \mathrm{H}_{5} \mathrm{CH}_{2} \mathrm{NH}_{3}\right)_{2} \mathrm{PbI}_{4}$ show redshift [36].

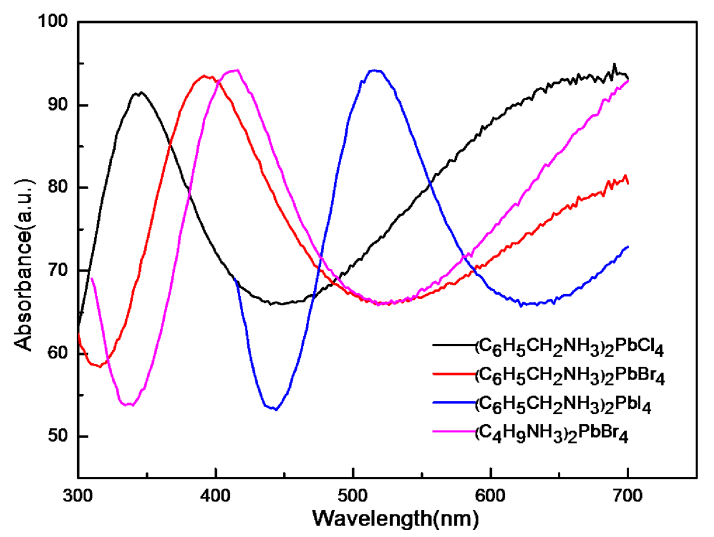

Figure 6. The UV-Vis absorption spectrum of $\left(\mathrm{C}_{6} \mathrm{H}_{5} \mathrm{CH}_{2} \mathrm{NH}_{3}\right)_{2} \mathrm{PbCl}_{4}$ (black curve), $\left(\mathrm{C}_{6} \mathrm{H}_{5} \mathrm{CH}_{2} \mathrm{NH}_{3}\right)_{2} \mathrm{PbBr}_{4}$ (red curve), $\left(\mathrm{C}_{6} \mathrm{H}_{5} \mathrm{CH}_{2} \mathrm{NH}_{3}\right)_{2} \mathrm{PbI}_{4}$ (blue curve) and $\left(\mathrm{C}_{4} \mathrm{H}_{9} \mathrm{NH}_{3}\right)_{2} \mathrm{PbBr}_{4}$ (pink curve). 
The absorption peaks of $\left(\mathrm{C}_{6} \mathrm{H}_{5} \mathrm{CH}_{2} \mathrm{NH}_{3}\right)_{2} \mathrm{PbBr}_{4}$ and $\left(\mathrm{C}_{4} \mathrm{H}_{9} \mathrm{NH}_{3}\right)_{2} \mathrm{PbBr}_{4}$ also show a redshift in Figure 6. For $\left(\mathrm{C}_{6} \mathrm{H}_{5} \mathrm{CH}_{2} \mathrm{NH}_{3}\right)_{2} \mathrm{PbBr}_{4}$ and $\left(\mathrm{C}_{4} \mathrm{H}_{9} \mathrm{NH}_{3}\right)_{2} \mathrm{PbBr}_{4}$ with the same inorganic layer $\mathrm{PbBr}_{2}$, it can be found that the forbidden band width of perovskite samples increases with the increase of the carbon chain length. We know that organic components have little contribution to this energy band. The valence band top and conduction band bottom of perovskite generally come from atomic orbitals in inorganic components. It shows that the organic components contribute little to this energy band, and that the valence band tops and conduction band bottoms of perovskites generally come from atomic orbitals in inorganic components. However, because the short chain has a stronger push electron effect than the long chain, the charge distribution between the inorganic and organic components changes, leading to the hydrogen bond interaction between the organic and inorganic layers changes. When the length of the carbon chain is shorter, the effect of the electron effect is strong, making the positive charge on the middle metal ion smaller, further increasing the strength of the hydrogen bond. The microstructure of the inorganic layer is changed due to the influence of the hydrogen bond, and the forbidden bandwidth is also adjusted. Therefore, organic components mainly affect the band gap through the hydrogen bond. Therefore, the absorption peak of $\left(\mathrm{C}_{4} \mathrm{H}_{9} \mathrm{NH}_{3}\right)_{2} \mathrm{PbBr}_{4}$ with a short carbon chain is higher than that of $\left(\mathrm{C}_{6} \mathrm{H}_{5} \mathrm{CH}_{2} \mathrm{NH}_{3}\right)_{2} \mathrm{PbBr}_{4}$ [37].

\subsection{The Laser Power Effect on the PL Intensity}

Figure 7a,c,e shows the bright field and dark field optical microscope images of the perovskites $\left(\mathrm{C}_{6} \mathrm{H}_{5} \mathrm{CH}_{2} \mathrm{NH}_{3}\right)_{2} \mathrm{PbBr}_{4},\left(\mathrm{C}_{6} \mathrm{H}_{5} \mathrm{CH}_{2} \mathrm{NH}_{3}\right)_{2} \mathrm{PbI}_{4}$ and $\left(\mathrm{C}_{4} \mathrm{H}_{9} \mathrm{NH}_{3}\right)_{2} \mathrm{PbBr}_{4}$, respectively. All of the perovskites present transparent crystals with regular geometric shapes. $\left(\mathrm{C}_{6} \mathrm{H}_{5} \mathrm{CH}_{2} \mathrm{NH}_{3}\right)_{2} \mathrm{PbBr}_{4}$ and $\left(\mathrm{C}_{4} \mathrm{H}_{9} \mathrm{NH}_{3}\right)_{2} \mathrm{PbBr}_{4}$ emit blue photoluminescence under the femtosecond laser, while $\left(\mathrm{C}_{6} \mathrm{H}_{5} \mathrm{CH}_{2} \mathrm{NH}_{3}\right)_{2} \mathrm{PbI}_{4}$ emit green photoluminescence. Figure $7 \mathrm{~b}$, d, $\mathrm{f}$ shows the PL spectrum of the perovskites $\left(\mathrm{C}_{6} \mathrm{H}_{5} \mathrm{CH}_{2} \mathrm{NH}_{3}\right)_{2} \mathrm{PbBr}_{4},\left(\mathrm{C}_{6} \mathrm{H}_{5} \mathrm{CH}_{2} \mathrm{NH}_{3}\right)_{2} \mathrm{PbI}_{4}$ and $\left(\mathrm{C}_{4} \mathrm{H}_{9} \mathrm{NH}_{3}\right)_{2} \mathrm{PbBr}_{4}$. PL peaks are located at $415 \mathrm{~nm}(2.98 \mathrm{eV}), 540 \mathrm{~nm}(2.30 \mathrm{eV})$ and $427 \mathrm{~nm}(2.81 \mathrm{eV})$, respectively. When the laser power increases from $10 \mathrm{~mW}$ to $100 \mathrm{~mW}$, the PL intensity of the perovskite $\left(\mathrm{C}_{6} \mathrm{H}_{5} \mathrm{CH}_{2} \mathrm{NH}_{3}\right)_{2} \mathrm{PbBr}_{4}$ increases from 117 to 2195 photon counts; the PL intensity of the perovskite $\left(\mathrm{C}_{6} \mathrm{H}_{5} \mathrm{CH}_{2} \mathrm{NH}_{3}\right)_{2} \mathrm{PbI}_{4}$ increases from 158 to 2771 photon counts; and the PL intensity of the perovskite $\left(\mathrm{C}_{4} \mathrm{H}_{9} \mathrm{NH}_{3}\right)_{2} \mathrm{PbBr}_{4}$ increases from 2320 to 13,224 photon counts.
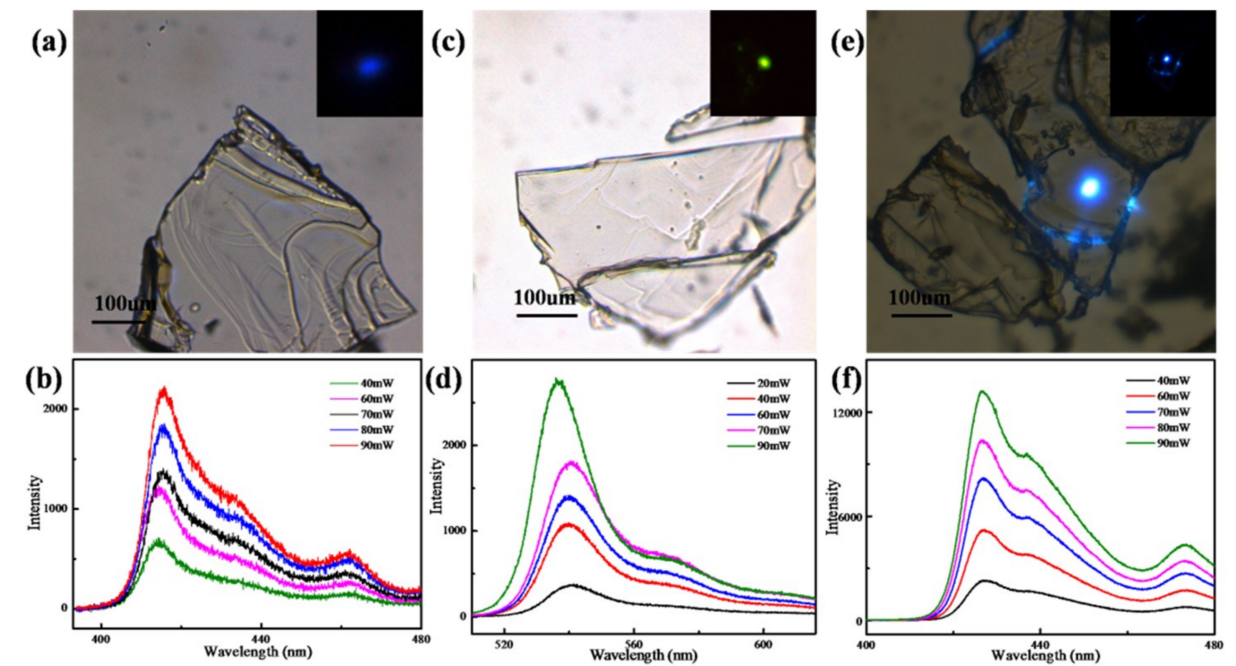

Figure 7. (a) The optical microscope images and (b) the two-photon PL spectrum of the perovskite $\left(\mathrm{C}_{6} \mathrm{H}_{5} \mathrm{CH}_{2} \mathrm{NH}_{3}\right)_{2} \mathrm{PbBr}_{4}$; (c) the optical microscope images and (d) the two-photon PL spectrum of the perovskite $\left(\mathrm{C}_{6} \mathrm{H}_{5} \mathrm{CH}_{2} \mathrm{NH}_{3}\right)_{2} \mathrm{PbI}_{4}$; (e) The optical microscope images and (f) the two-photon PL spectrum of the perovskite $\left(\mathrm{C}_{4} \mathrm{H}_{9} \mathrm{NH}_{3}\right)_{2} \mathrm{PbBr}_{4}$. 
It can be seen that the photoluminescence intensity increases with the increase of laser power. Because the interaction between photons and perovskite molecules is strengthened with the increase of light intensity, a large number of electrons and holes will be generated inside the perovskite molecules. The recombination of electrons and holes will release the excess energy in the form of photoluminescence, so the photoluminescence intensity increases with the increase of laser power [38].

It was found that $\left(\mathrm{C}_{6} \mathrm{H}_{5} \mathrm{CH}_{2} \mathrm{NH}_{3}\right)_{2} \mathrm{PbBr}_{4}$ and $\left(\mathrm{C}_{6} \mathrm{H}_{5} \mathrm{CH}_{2} \mathrm{NH}_{3}\right)_{2} \mathrm{PbI}_{4}$ had a significant difference in the strongest PL peak, and a longer PL wavelength with a higher halogen atomic number. The band gap of $\mathrm{PbBr}_{2}$ is larger than that of $\mathrm{PbI}_{2}$ in the inorganic part, resulting in the increase of exciton binding energy of $\left(\mathrm{C}_{6} \mathrm{H}_{5} \mathrm{CH}_{2} \mathrm{NH}_{3}\right)_{2} \mathrm{PbBr}_{4}$. Therefore, the $\mathrm{PL}$ spectrum of $\left(\mathrm{C}_{6} \mathrm{H}_{5} \mathrm{CH}_{2} \mathrm{NH}_{3}\right)_{2} \mathrm{PbBr}_{4}$ and $\left(\mathrm{C}_{6} \mathrm{H}_{5} \mathrm{CH}_{2} \mathrm{NH}_{3}\right)_{2} \mathrm{PbI}_{4}$ show a redshift. We can see that the PL spectrum of $\left(\mathrm{C}_{6} \mathrm{H}_{5} \mathrm{CH}_{2} \mathrm{NH}_{3}\right)_{2} \mathrm{PbBr}_{4}$ and $\left(\mathrm{C}_{4} \mathrm{H}_{9} \mathrm{NH}_{3}\right)_{2} \mathrm{PbBr}_{4}$ have two peaks. The lower peak is the photonic exciton generated by the inorganic layer. Binding exciton produces binding energy and emits photons with Coulomb forces after electron hole pair transition of excitons in perovskite. Therefore, the low peak is thought to be generated by the radiation excitation of excitons. At the higher peak, it can be found that compared with the front exciton emission peak, the peak width of the peak is very wide, and the energy of the luminescent peak is smaller than that of the front exciton emission peak. The existence of the peak is attributed to the luminescence caused by crystal defects. In the actual crystal, due to the arrangement of the crystal itself, the point defect, line defect and plane defect will appear in the crystal, which will affect the photoluminescence of the substance itself, resulting in higher defect luminescence peak.

\subsection{The Laser Power Effect on the PL Lifetime}

Figure 8a-c shows the lifetime of the two-photon PL emission (pumped at $800 \mathrm{~nm}$ ) from the perovskite $\left(\mathrm{C}_{6} \mathrm{H}_{5} \mathrm{CH}_{2} \mathrm{NH}_{3}\right)_{2} \mathrm{PbBr}_{4},\left(\mathrm{C}_{6} \mathrm{H}_{5} \mathrm{CH}_{2} \mathrm{NH}_{3}\right)_{2} \mathrm{PbI}_{4}$ and $\left(\mathrm{C}_{4} \mathrm{H}_{9} \mathrm{NH}_{3}\right)_{2} \mathrm{PbBr}_{4}$. When the laser power increases from $10 \mathrm{~mW}$ to $100 \mathrm{~mW}$, the PL lifetime of $\left(\mathrm{C}_{6} \mathrm{H}_{5} \mathrm{CH}_{2} \mathrm{NH}_{3}\right)_{2} \mathrm{PbBr}_{4}$ decreases from 0.75 ns to $0.50 \mathrm{~ns},\left(\mathrm{C}_{6} \mathrm{H}_{5} \mathrm{CH}_{2} \mathrm{NH}_{3}\right)_{2} \mathrm{PbI}_{4}$ decreases from $0.67 \mathrm{~ns}$ to $0.46 \mathrm{~ns}$, and $\left(\mathrm{C}_{4} \mathrm{H}_{9} \mathrm{NH}_{3}\right)_{2} \mathrm{PbBr}_{4}$ decreases from 3.02 ns to 2.29 ns.
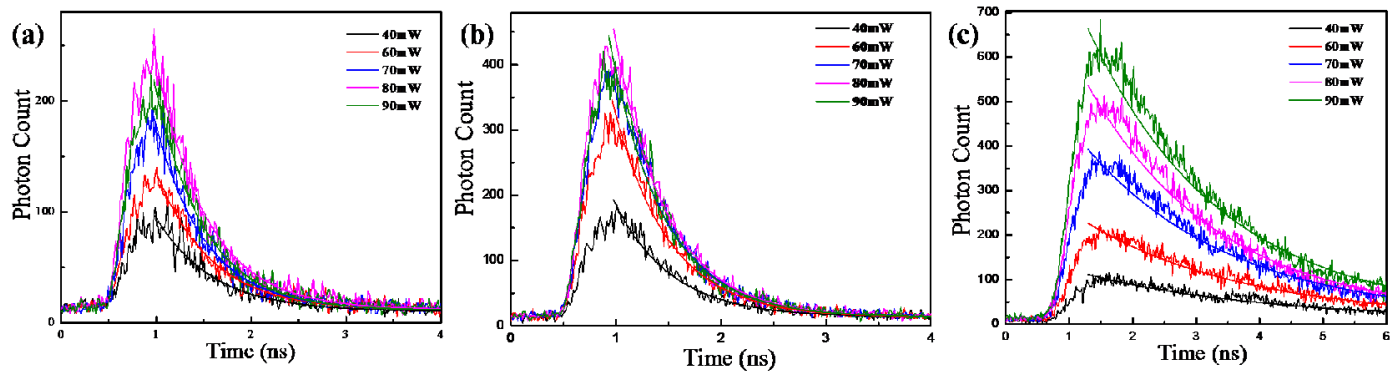

Figure 8. The PL lifetime profile of the perovskite (a) $\left(\mathrm{C}_{6} \mathrm{H}_{5} \mathrm{CH}_{2} \mathrm{NH}_{3}\right)_{2} \mathrm{PbBr}_{4}$, (b) $\left(\mathrm{C}_{6} \mathrm{H}_{5} \mathrm{CH}_{2} \mathrm{NH}_{3}\right)_{2} \mathrm{PbI}_{4}$ and (c) $\left(\mathrm{C}_{4} \mathrm{H}_{9} \mathrm{NH}_{3}\right)_{2} \mathrm{PbBr}_{4}$.

It can be seen that the PL lifetime of $\left(\mathrm{C}_{6} \mathrm{H}_{5} \mathrm{CH}_{2} \mathrm{NH}_{3}\right)_{2} \mathrm{PbBr}_{4}$ is longer than that of $\left(\mathrm{C}_{6} \mathrm{H}_{5} \mathrm{CH}_{2} \mathrm{NH}_{3}\right)_{2} \mathrm{PbI}_{4}$ at the same laser power. This is because the atomic radius of $\mathrm{Br}$ and $\mathrm{I}$ increases in turn, which makes the framework of $\mathrm{PbX}_{2}$ in the inorganic layer increase in turn, and the forbidden bandwidth of $\mathrm{PbBr}_{2}$ and $\mathrm{PbI}_{2}$ in the inorganic part decrease in turn, resulting in the decrease of exciton binding energy. Therefore, the excitons of $\left(\mathrm{C}_{6} \mathrm{H}_{5} \mathrm{CH}_{2} \mathrm{NH}_{3}\right)_{2} \mathrm{PbI}_{4}$ are easier to separate and emit compound fluorescence. Thus, the PL lifetime of $\left(\mathrm{C}_{6} \mathrm{H}_{5} \mathrm{CH}_{2} \mathrm{NH}_{3}\right)_{2} \mathrm{PbBr}_{4}$ is longer than that of $\left(\mathrm{C}_{6} \mathrm{H}_{5} \mathrm{CH}_{2} \mathrm{NH}_{3}\right)_{2} \mathrm{PbI}_{4}$ at the same laser power.

It also can be seen that the PL lifetime of $\left(\mathrm{C}_{4} \mathrm{H}_{9} \mathrm{NH}_{3}\right)_{2} \mathrm{PbBr}_{4}$ is longer than that of $\left(\mathrm{C}_{6} \mathrm{H}_{5} \mathrm{CH}_{2} \mathrm{NH}_{3}\right)_{2} \mathrm{PbBr}_{4}$ at the same laser power. The organic amine cation of $\left(\mathrm{C}_{6} \mathrm{H}_{5} \mathrm{CH}_{2} \mathrm{NH}_{3}\right)_{2} \mathrm{PbBr}_{4}$ shows disorder, which leads to greater thermal vibration and more electron scattering phonons, leading to non-radiation transition and a sharp decrease of its PL life. Therefore, the PL lifetime of $\left(\mathrm{C}_{6} \mathrm{H}_{5} \mathrm{CH}_{2} \mathrm{NH}_{3}\right)_{2} \mathrm{PbBr}_{4}$ is less than that of $\left(\mathrm{C}_{4} \mathrm{H}_{9} \mathrm{NH}_{3}\right)_{2} \mathrm{PbBr}_{4}$ at the same laser power. 
The relationship of PL intensity and lifetime with laser power can be explained with the energy level diagram [39-42], as shown in Figure 9. Under the excitation of $800 \mathrm{~nm}$ femtosecond laser, the perovskite molecules absorb two photons, exciting the electrons at the top of the valence band to the bottom of the conduction band. Some electrons from the bottom of the conduction band will go back to the top of the valence band, releasing the excess energy in the form of photoluminescence. The electrons at the bottom of the conduction band also relax to the defect state on the electron surface and then return to the top of the valence band and compound photoluminescence with the defect state. The emission intensity is related to the absorption cross section of two photons. As the laser power continues to increase, more and more electrons are excited to the bottom of the conduction band. Some of the electrons at the bottom of the conduction band return to the top of the valence band, and another part relaxes to the defect state of the electron surface and then returns to the top of the valence band. In this process, carrier density increases and the non-geminate recombination plays a dominant role. Therefore, the two-photon PL intensity increases with the increase of laser power, while the PL lifetime decreases with the increase of laser power [43].

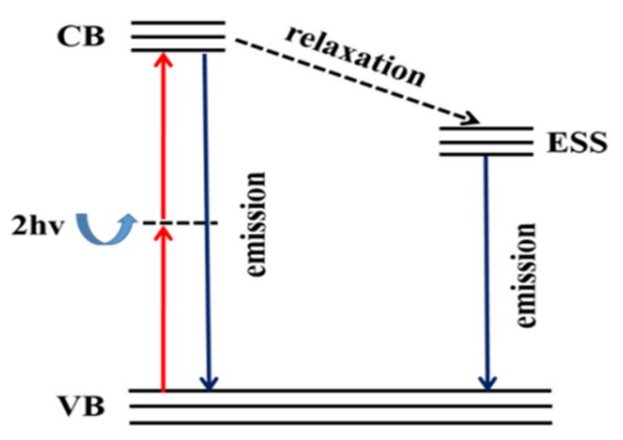

Figure 9. Energy level schemes of the perovskites. VB, valence band; CB, conduction band; ESSs, electron surface defect states; relaxation, the relaxation process; emission, emission process; hv, the energy of a single photon.

\section{Conclusions}

Four organic-inorganic hybrid perovskites of $\left(\mathrm{C}_{6} \mathrm{H}_{5} \mathrm{CH}_{2} \mathrm{NH}_{3}\right)_{2} \mathrm{PbCl}_{4},\left(\mathrm{C}_{6} \mathrm{H}_{5} \mathrm{CH}_{2} \mathrm{NH}_{3}\right)_{2} \mathrm{PbBr}_{4}$, $\left(\mathrm{C}_{6} \mathrm{H}_{5} \mathrm{CH}_{2} \mathrm{NH}_{3}\right)_{2} \mathrm{PbI}_{4}$ and $\left(\mathrm{C}_{4} \mathrm{H}_{9} \mathrm{NH}_{3}\right)_{2} \mathrm{PbBr}_{4}$ were successfully prepared by solvent evaporation. The crystal structure, surface morphology and optical properties of perovskites materials were studied by X-ray diffraction, transmission electron microscopy, fluorescence spectrophotometer, ultraviolet-visible spectrophotometer and optical confocal microscopy. The effects of different halogens and organic amines on perovskite absorption spectra and PL spectra were investigated. The experimental results show that under the same conditions of organic amines, with the increase of halogen atomic number, halogen radius and corresponding perovskite cell volume increase, perovskite interlayer spacing shows a trend of increasing in turn; the framework of inorganic layer $\mathrm{PbX}_{2}$ increases in turn, and the forbidden bandwidth of inorganic layer $\mathrm{PbX}_{2}$ decreases in turn, resulting in the decrease of the exciton binding energy. The binding energy decreases in turn, the peak value of UV-Vis absorption spectra appears to redshift, and the PL lifetime decreases in turn. Under the same inorganic layer, different organic amines will distort the inorganic framework and affect the luminescence properties of perovskite, but organic amines have little effect on the exciton luminescence of perovskites. With the increase of laser power, the two-photon PL intensity of perovskite increases with the increase of laser power, while the PL lifetime decreases with the increase of laser power, mainly the non-geminate recombination. With the development of research on organic-inorganic hybrid perovskite materials, we can prepare hybrid perovskites by changing the composition of inorganic and organic materials, to realize their spectral regulation, promoting better use in solar materials, photoelectric sensors, micro-lasers, and other optoelectronic devices. 
Author Contributions: Y.L., S.L., F.Y., L.X. and Z.H. completed the experiments; F.L. and Y.L. wrote the paper; F.L., X.H. and K.W. revised the paper.

Funding: This research was funded by the National Natural Science Foundation of China (Grant No. 11204222); The Natural Science Foundation of Hubei Province, China (Grant No. 2013CFB316, Grant No. 2014CFB793); The Innovation Fund of School of Science, Wuhan Institute of Technology (No. CX2016106).

Acknowledgments: The authors would like to thank the support of Lu Peixiang's Group in Huazhong University of Science and Technology.

Conflicts of Interest: The authors declare no conflicts of interest.

\section{References}

1. Saparov, B.; Mitzi, D.B. Organic Inorganic Perovskites: Structural Versatility for Functional Materials Design. Chem. Rev. 2016, 116, 4558-4596. [CrossRef]

2. Li, W.; Wang, Z.; Deschler, F.; Gao, S.; Friend, R.H.; Cheetham, A.K. Chemically diverse and multifunctional hybrid organic inorganic perovskites. Nat. Rev. Mater. 2017, 2, 16099. [CrossRef]

3. Shi, E.; Gao, Y.; Finkenauer, B.P.; Akriti Coffey, A.H.; Dou, L. Two-dimensional halide perovskite nanomaterials and heterostructures. Chem. Soc. Rev. 2018, 47, 6046-6072. [CrossRef] [PubMed]

4. Tian, Y.; Merdasa, A.; Unger, E.; Abdellah, M.; Zheng, K.; Mckibbin, S.; Mikkelsen, A.; Pullerits, T.; Yartsev, A.; Sundstrom, V.; et al. Enhanced Organo-Metal Halide Perovskite Photoluminescence from Nanosized Defect-Free Crystallites and Emitting Sites. J. Phys. Chem. Lett. 2015, 6, 4171-4177. [CrossRef] [PubMed]

5. Kim, T.W.; Uchida, S.; Matsushita, T.; Cojocaru, L.; Jono, R.; Kimura, K.; Matsubara, D.; Shirai, M.; Mastsumoto, H.; Kondo, T.; et al. Self-Organized Superlattice and Phase Coexistence inside Thin Film Organometal Halide Perovskite. Adv. Mater. 2018, 30, 1705230. [CrossRef]

6. Dong, L.Y.; Sun, S.J.; Deng, Z.Y.; Li, W.; Wei, F.X.; Qi, Y.J.; Li, Y.C.; Li, X.D.; Lu, P.X.; Ramamurty, U. Elastic properties and thermal expansion of lead-free halide double perovskite $\mathrm{Cs}_{2} \mathrm{AgBiBr}_{6}$. Comput. Mater. Sci. 2018, 141, 49-58.

7. Zhang, L.; Liang, W.Z. How the Structures and Properties of Two-Dimensional Layered Perovskites $\mathrm{MAPbI}_{3}$ and $\mathrm{CsPbI}_{3}$ Vary with the Number of Layers. J. Phys. Chem. Lett. 2017, 8, 1517-1523. [CrossRef]

8. Mitzi, D.B. Templating and structural engineering in organic-inorganic perovskites. J. Chem. Soc. Dalton Trans. 2001, 1, 1-12. [CrossRef]

9. Hong, X.; Ishihara, T.; Nurmikko, A.V. Photoconductivity and electroluminescence in lead iodide based natural quantum well structures. Solid State Commun. 1992, 84, 657-661. [CrossRef]

10. Mitzi, D.B. ChemInform Abstract: Synthesis, Structure, and Properties of Organic-Inorganic Perovskites and Related Materials. ChemInform 2010, 30. [CrossRef]

11. Umebayashi, T.; Asai, K.; Kondo, T.; Nakao, A. Electronic structures of lead iodide based low-dimensional crystals. Phys. Rev. B 2003, 67, 155405. [CrossRef]

12. Yuan, Z.; Shu, Y.; Tian, Y.; Xin, Y.; Ma, B.W. A facile one-pot synthesis of deep blue luminescent lead bromide perovskite microdisks. Chem. Commun. 2015, 51, 16385-16388. [CrossRef] [PubMed]

13. Yaffe, O.; Chernikov, A.; Norman, Z.M.; Zhong, Y.; Velauthapillai, A.; Zande, A.; Owen, J.S.; Heinz, T.F. Excitons in ultrathin organic-inorganic perovskite crystals. Phys. Rev. B 2015, 92, 045414. [CrossRef]

14. Brenner, T.M.; Egger, D.A.; Kronik, L.; Hodes, G.; Cahen, D. Hybrid organic-Inorganic perovskites: Low-cost semiconductors with intriguing charge-transport properties. Nat. Rev. Mater. 2016, 1, 15007. [CrossRef]

15. Han, X.B.; Wang, K.; Long, H.; Hu, H.B.; Chen, J.W.; Wang, B.; Lu, P.X. Highly sensitive detection of the lattice distortion in single bent $\mathrm{ZnO}$ nanowires by second harmonic generation microscopy. ACS Photonics 2016, 3, 1308-1314. [CrossRef]

16. Zhang, S.J.; Audebert, P.; Wei, Y.; AIC, A.; Lanty, G.; Brehier, A.; Galmiche, L.; Clavier, G.; Boissiere, C.; Lauret, J.S.; et al. Preparations and Characterizations of Luminescent Two Dimensional Organic-inorganic Perovskite Semiconductors. Materials 2010, 3, 3385-3406. [CrossRef]

17. Kawano, N.; Koshimizu, M.; Sun, Y.; Yahaba, N.; Fujimoto, Y.; Yanagida, T.; Asai, K. Effects of Organic Moieties on Luminescence Properties of Organic-Inorganic Layered Perovskite-Type Compounds. J. Phys. Chem. C 2014, 118, 9101-9106. [CrossRef] 
18. Qin, P.L.; Lei, H.W.; Zheng, X.L.; Liu, Q.; Tao, H.; Yang, G.; Ke, W.J.; Xiong, L.B.; Qin, M.C.; Zhao, X.Z.; et al. Copper-Doped Chromium Oxide Hole-Transporting Layer for Perovskite Solar Cells: Interface Engineering and Performance Improvement. Adv. Mater. Interfaces 2016, 3, 1500799. [CrossRef]

19. Deng, Q.R.; Li, Y.Q.; Chen, L.A.; Wang, S.G.; Wang, G.M.; Sheng, Y.L.; Shao, G.S. The effects of electron and hole transport layer with the electrode work function on perovskite solar cells. Mod. Phys. Lett. B 2016, 30, 1650341. [CrossRef]

20. Qin, P.L.; He, Q.; Dan, O.Y.; Fang, G.J.; Choy, W.C.H.; Li, G. Transition metal oxides as hole-transporting materials in organic semiconductor and hybrid perovskite based solar cells. Sci. China Chem. 2017, 60, 472-489. [CrossRef]

21. Qin, X.; Dong, H.L.; Hu, W.P. Green light-emitting diode from bromine based organic inorganic halide perovskite. Sci. China Mater. 2015, 58, 186-191. [CrossRef]

22. Tan, Z.K.; Moghaddam, R.S.; Lai, M.L.; Docampo, P.; Higler, R.; Deschler, F.; Price, M.; Sadhanala, A.; Pazos, L.M.; Credgington, D.; et al. Bright light emitting diodes based on organometal halide perovskite. Nat. Nanotechnol. 2014, 9, 687-692. [CrossRef] [PubMed]

23. Xu, L.T.; Li, F.; Wei, L.; Zhou, J.X.; Liu, S. Design of Surface Plasmon Nanolaser Based on MoS 2 . Appl. Sci. 2018, 8, 2110. [CrossRef]

24. Xu, L.T.; Li, F.; Liu, S.; Yao, F.Q.; Liu, Y.H. Low Threshold Plasmonic Nanolaser Based on Graphene. Appl. Sci. 2018, 8, 2186. [CrossRef]

25. Xu, L.T.; Li, F.; Liu, Y.; Yao, F.Q.; Liu, S. Surface Plasmon Nanolaser: Principle, Structure, Characteristics and Applications. Appl. Sci. 2019, 9, 861. [CrossRef]

26. Stoumpos, C.C.; Malliakas, C.D.; Peters, J.; Liu, Z.F.; Sebastian, M.; Im, J.; Chasapis, T.; Wibowo, A.;

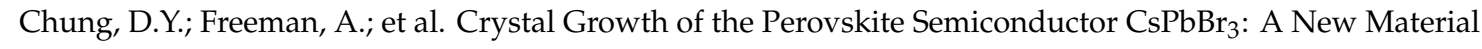
for High Energy Radiation Detection. Crys. Grow. Des. 2013, 13, 2722-2727. [CrossRef]

27. Dou, L.; Yang, Y.M.; You, J.; Hong, Z.R.; Chang, W.H.; Li, G.; Yang, Y. Solution processed hybrid perovskite photodetectors with high detectivity. Nat. Commun. 2014, 5, 5404. [CrossRef]

28. Kojima, A.; Teshima, K.; Shirai, Y.; Miyasaka, T. Organometal Halide Perovskites as Visible Light Sensitizers for Photovoltaic Cells. J. Am. Chem. Soc. 2009, 131, 6050-6051. [CrossRef]

29. Kawano, N.; Koshimizu, M.; Asai, K. The Effect of Wannier and Frenkel Exciton Resonance on the Luminescence Properties of Organic Inorganic Layered Perovskite-Type Compounds. J. Am. Chem. Soc. 2012, 116, 22992-22995. [CrossRef]

30. Slavney, A.H.; Hu, T.; Lindenberg, A.M.; Karunadasa, H.I. A Bismuth-Halide Double Perovskite with Long Carrier Recombination Lifetime for Photovoltaic Applications. J. Am. Chem. Soc. 2016, 138, $2138-2141$. [CrossRef]

31. Hu, X.; Zhou, H.; Jiang, Z.; Wang, X.; Yuan, S.P.; Lan, J.Y.; Fu, Y.P.; Zhang, X.H.; Zheng, W.H.; Wang, X.X.; et al. Direct Vapor Growth of Perovskite $\mathrm{CsPbBr}_{3}$ Nanoplate Electroluminescence Devices. ACS Nano. 2017, 11, 9869-9876. [CrossRef] [PubMed]

32. Chen, J.; Gan, L.; Zhuge, F.; Li, H.; Song, J.; Zeng, H.; Zhai, T. A Ternary Solvent Method for Large Sized Two Dimensional Perovskites. Angew. Chem. Int. Ed. 2017, 56, 2390-2394. [CrossRef] [PubMed]

33. Luo, D.; Yang, W.; Wang, Z.; Wang, Z.P.; Sadhanala, A.; Hu, Q.; Su, R.; Shivanna, R.; Trindade, G.F.; Watts, J.F.; et al. Enhanced photovoltage for inverted planar heterojunction perovskite solar cells. Science 2018, 360, 1442-1446. [CrossRef]

34. Chen, C.; He, Y.C.; Du, Z.P.; Yuan, H.; Wu, Y.X. Preparation and properties of perovskite-type $\mathrm{La}_{0.5} \mathrm{~Pb}_{0.5} \mathrm{MnO}_{3}$ by stearic acid method. Mater. Lett. 2013, 110, 264-266. [CrossRef]

35. Liao, W.Q.; Zhang, Y.; Hu, C.L.; Mao, J.G.; Ye, H.Y.; Li, P.F.; Huang, S.D.; Xiong, R.G. A lead halide perovskite molecular ferroelectric semiconductor. Nat. Commun. 2015, 6, 7338. [CrossRef] [PubMed]

36. Papavassiliou, G.C.; Mousdis, G.A.; Raptopoulou, C.P. Preparation and characterization of perovskite $\left(\mathrm{C}_{6} \mathrm{H}_{5} \mathrm{CH}_{2} \mathrm{NH}_{3}\right)_{2} \mathrm{PbI}_{4},\left[\mathrm{C}_{6} \mathrm{H}_{5} \mathrm{C}_{2} \mathrm{H}_{4} \mathrm{SC}\left(\mathrm{NH}_{2}\right)_{2}\right]_{3} \mathrm{PbI}_{5}$ and $\left(\mathrm{C}_{10} \mathrm{H}_{7} \mathrm{CH}_{2} \mathrm{NH}_{3}\right)_{2} \mathrm{PbI}_{3}$ organic inorganic hybrid compounds. Z. Nat. B 1999, 54, 1405-1409.

37. Dou, L.; Wong, A.B.; Yu, Y.; Lai, M.L.; Kornienko, N.; Eaton, S.W.; Fu, A.; Bischak, C.G.; Ma, J.; Ding, T.; et al. Atomically thin twodimensionalorganicinorganic hybrid perovskites. Science 2015, 349, 1518-1521. [CrossRef]

38. Xu, W.; Mcleod, J.A.; Yang, Y.; Wang, Y.; Wu, Z.W.; Bai, S.; Yuan, Z.C.; Song, T.; Wang, Y.S.; Si, J.J.; et al. Iodomethane Mediated Organometal Halide Perovskite with Record Photoluminescence Lifetime. ACS Appl. Mater. Interfaces 2016, 8, 23181. [CrossRef] 
39. Li, F.; He, Z.C.; Li, M.Y.; Zhang, J.P.; Han, J.B.; Lu, P.X. Photoinduced energy transfer in a CdTe quantum dot copper phthalocyanine system via two photon excitation. Mater. Lett. 2014, 132, 263-266. [CrossRef]

40. Li, F.; Lu, P.X.; Long, H.; Yang, G.; Li, Y.H.; Zheng, Q.G. Nonlinear absorption in CuPc-doped PMMA thin film in the femtosecond regime: Experimental and theoretical studies. Opt. Express 2008, 16, 14571-14581. [CrossRef]

41. Li, F.; He, Z.; Li, M.; Lu, P. Three-photon absorption of copper phthalocyanine solution by femtosecond Z-scan technique. Mater. Lett. 2013, 111, 81-84. [CrossRef]

42. Li, F.; Li, X. Theoretical investigation on nonlinear absorption of multilevel organic molecular system in $\mathrm{ns}$, ps and fs regime. Opt. Commun. 2012, 285, 5217-5222. [CrossRef]

43. Liu, W.W.; Li, X.H.; Song, Y.L.; Zhang, C.; Han, X.B.; Long, H.; Wang, B.; Wang, K.; Lu, P.X. Cooperative Enhancement of Two Photon Absorption Induced Photoluminescence from a 2D Perovskite Microsphere Hybrid Dielectric Structure. Adv. Funct. Mater. 2018, 28, 1707550. [CrossRef]

(C) 2019 by the authors. Licensee MDPI, Basel, Switzerland. This article is an open access article distributed under the terms and conditions of the Creative Commons Attribution (CC BY) license (http://creativecommons.org/licenses/by/4.0/). 